\title{
Risk groups and other target groups - preliminary ECDC guidance for developing influenza vaccination recommendations for the season 2010-11
}

H Nokleby (Hanne.Nokelby@ecdc.europa.eu) ${ }^{1}$, A Nicoll ${ }^{1}$

1. European Centre for Disease Prevention and Control (ECDC), Stockholm, Sweden

Citation style for this article:

Citation style for this article: Nokleby H, Nicoll A. Risk groups and other target groups - preliminary ECDC guidance for developing influenza vaccination

recommendations for the season 2010-11. Euro Surveill. 2010;15(12):pii=19525. Available online: http://www.eurosurveillance.org/ViewArticle.

aspx?Articleld=19525

This article has been published on 25 March 2010

Providing guidance on risk and target groups for seasonal influenza immunisation is difficult for the 201011 season since there is no experience with the new influenza $A\left(\mathrm{H}_{1} \mathrm{~N}_{1}\right)$ virus in its seasonal form. Arguments exist for offering immunisation to people with chronic illness and older people, and also for other risk and target groups including pregnant women. A more rigorous approach is being developed to produce annual evidence-based guidance on risk and target groups for influenza vaccination.

The 2009 influenza $A\left(\mathrm{H}_{1} \mathrm{~N}_{1}\right)$ pandemic has changed the landscape for seasonal influenza [1]. While more than one scenario is possible for the next influenza season (2010-11) the most likely prospect identified in a Forward Look Risk Assessment by the European Centre for Disease Prevention and Control (ECDC) is that the new influenza $A\left(\mathrm{H}_{1} \mathrm{~N}_{1}\right)$ virus will dominate [2]. Such a 'new' seasonal influenza will be different from the 'old' influenza and presumably have similarities to the autumn/winter pandemic wave of 2009 (Table 1), although there will presumably be less transmission because of immunity in the population following the 2009 transmission and immunisation programmes.

The presence of drifted influenza $\mathrm{A}\left(\mathrm{H}_{3} \mathrm{~N}_{2}\right)$ viruses cannot be ruled out and influenza $B$ viruses will be an inevitability [2]. Pandemic strains also always change, and another possibility is a drifted influenza $A\left(\mathrm{H}_{1} \mathrm{~N}_{1}\right)$ virus with somewhat different properties such as higher transmissibility or higher morbidity in older people. It is currently unknown if infection or vaccination in 2009 and early 2010 will result in immunity and protection in that situation, and the World Health Organization (WHO) and the European Medicines Agency (EMA) have recommended all three antigens for next season's vaccines (pandemic influenza $A\left(\mathrm{H}_{1} \mathrm{~N}_{1}\right)$, influenza $A\left(\mathrm{H}_{3} \mathrm{~N}_{2}\right)$ and influenza B) [7].

A more severe season than the autumn/winter wave of 2009-10 cannot entirely be excluded [2]. This happened in the second winter of the last ('Hong Kong') pandemic when the virus became more transmissible and killed more people in its second European season (1969-70) than in 1968-69 [2,8]. Under those circumstances the unused stocks of the adjuvanted pandemic vaccines with a very good safety profile would be invaluable, provided that the necessary stability for use next autumn is documented.

Particular uncertainty arises over the risk groups and target groups. This is important as in European countries the influenza vaccination strategy is based on protecting the vulnerable. ECDC has previously produced evidence-based guidance to help European Union (EU) Member States decide on these groups. This was done based on the evidence from interpandemic (seasonal) influenza from 1970 to 2007 [9]. ECDC is obliged to produce such guidance annually under a new Health Council Recommendation that foresees the following [10]:

The Member States are encouraged to adopt and implement national, regional or local action plans aimed at improving seasonal influenza vaccine coverage to a coverage rate of $75 \%$ for older age groups and if possible for other risk groups, preferably by the 2014-15 season;

- The Member States' action plans and policies are to take into account definitions of older age groups and risk groups as contained in guidance by ECDC as well as measurements of uptake in all risk groups and analyses of why some people do not wish to receive vaccination;

- The Member States are to foster education, training and information exchange on seasonal influenza and vaccination by organising information action for healthcare workers, information action for risk groups and their families, and organising effective information to remove obstacles to vaccination uptake;

- The Member States are invited to report on a voluntary basis to the Commission on the implementation of this recommendation, in particular vaccination coverage achieved among risk groups; 
- The Commission is invited to report regularly to the Council on the implementation of this recommendation, on the basis of the data the Member States will make available.

With a new seasonal influenza based on a pandemic virus that behaved differently from the old seasonal influenza (Table 1), solid evidence-based guidance cannot be produced at present. However, a number of countries have to order vaccines for the coming season now, and the size of those orders depends on decisions on which groups to immunise. The objective of this paper is to satisfy its new obligation and to answer questions received from countries by discussing the issues that they should take into consideration when making such decisions.

There is one particularly important difference between the coming season and the pandemic period. When risk groups and other target groups for pandemic vaccines were identified in the summer of 2009 by the WHO Strategic Advisory of experts on Immunization (SAGE) [11] and the EU Health Security Committee, the initial vaccine supply was limited and had to be rigorously

\section{TABLE 1}

Differences between old seasonal influenza and 2009 pandemic influenza in Europe

\begin{tabular}{|c|c|c|}
\hline & Seasonal influenza 1970-2008 & 2009 pandemic influenza \\
\hline $\begin{array}{l}\text { Circulating influenza } \\
\text { viruses }\end{array}$ & $\begin{array}{l}\text { Two influenza } A \text { viruses: } A\left(\mathrm{H}_{1} \mathrm{~N}_{1}\right), A\left(\mathrm{H}_{3} \mathrm{~N}_{2}\right) \text { and some } \\
\text { influenza } B \text { viruses }\end{array}$ & $\begin{array}{l}\text { Almost exclusively pandemic influenza } A\left(\mathrm{H}_{1} \mathrm{~N}_{1}\right) \text {, a few } \\
\text { influenza } A\left(\mathrm{H}_{3} \mathrm{~N}_{2}\right) \text { and some influenza } B \text { viruses }\end{array}$ \\
\hline Antiviral resistance & $\begin{array}{l}\text { Common and transmissible oseltamivir resistance in } \\
\text { influenza } A\left(\mathrm{H}_{1} \mathrm{~N}_{1}\right) \text { viruses }(2008-9) \text { and adamantane } \\
\text { resistance in influenza } A\left(\mathrm{H}_{3} \mathrm{~N}_{2}\right) \text { viruses }\end{array}$ & $\begin{array}{l}\text { Rare and to date only transmitting under certain } \\
\text { circumstances }\end{array}$ \\
\hline Setting for transmission & Probably any setting where people come together & $\begin{array}{l}\text { Schools are considered especially important, along with } \\
\text { homes }\end{array}$ \\
\hline $\begin{array}{l}\text { Experiencing severe } \\
\text { disease }\end{array}$ & Those in clinical risk groups and older people & $\begin{array}{l}\text { Young children, pregnant women and those in clinical } \\
\text { risk groups, but } 20-30 \% \text { of people experiencing severe } \\
\text { disease were outside any risk group } \\
\text { Many people born before the mid-1950s seem to be } \\
\text { immune, but those who are not do experience severe } \\
\text { disease, more so than any other age group. }\end{array}$ \\
\hline $\begin{array}{l}\text { Acute respiratory } \\
\text { distress syndrome }\end{array}$ & Extremely rare & Uncommon but does occur, even in young fit adults. \\
\hline Mortality & $\begin{array}{l}\text { Few confirmed deaths reported each year in official } \\
\text { statistics } \\
\text { Estimates of up to } 40,000 \text { deaths in a more severe year } \\
\text { in the European Union (EU) using statistical methods [3] } \\
\text { based on European data }[4,5]\end{array}$ & $\begin{array}{l}\text { Substantial numbers of confirmed deaths announced by } \\
\text { the EU Member States (over } 2,800 \text { deaths as of March } \\
2010 \text { ) } \\
\text { Not yet calculated for the EU, but estimated in the } \\
\text { United States at over } 11,000 \text { deaths [6] }\end{array}$ \\
\hline
\end{tabular}

TABLE 2

Risk groups for seasonal influenza 2008-9 and pandemic influenza 2009

\begin{tabular}{|c|c|c|c|c|}
\hline & \multicolumn{2}{|c|}{ Seasonal influenza up to $2008-9$} & \multicolumn{2}{|c|}{ Pandemic influenza 2009} \\
\hline & $\begin{array}{l}\text { Risk of severe disease and } \\
\text { death }\end{array}$ & Vaccine effectiveness & $\begin{array}{l}\text { Risk of severe disease and } \\
\text { death }\end{array}$ & Comments \\
\hline \multicolumn{5}{|l|}{ Potential risk groups } \\
\hline $\begin{array}{l}\text { Persons with } \\
\text { chronic diseases }\end{array}$ & Increased, well documented & Limited documentation & Increased, well documented & $\begin{array}{l}\text { Included people with } \\
\text { morbid obesity and children } \\
\text { with neurodevelopmental } \\
\text { conditions }\end{array}$ \\
\hline Older people & Increased, well documented & Reasonable documentation & $\begin{array}{l}\text { Low incidence, but highest } \\
\text { risk of complications of any } \\
\text { age group if infected }\end{array}$ & \\
\hline Pregnant women & $\begin{array}{l}\text { Possibly increased, limited } \\
\text { documentation }\end{array}$ & Unclear & $\begin{array}{l}\text { Increased risk of } \\
\text { complications }\end{array}$ & $\begin{array}{l}\text { Limited data and } \\
\text { documentation from Europe } \\
\text { [9] }\end{array}$ \\
\hline Children & $\begin{array}{l}\text { High incidence, } \\
\text { complication risk moderate }\end{array}$ & Good documentation & $\begin{array}{l}\text { Increased risk of } \\
\text { hospitalisations, less risk of } \\
\text { severe disease }\end{array}$ & \\
\hline Healthy adults & Low & Good documentation & $\begin{array}{l}\text { Increased risk of severe } \\
\text { disease and death }\end{array}$ & \\
\hline \multicolumn{5}{|c|}{ Target groups for vaccination } \\
\hline Healthcare workers & NA & $\begin{array}{l}\text { Some documentation } \\
\text { of reduced incidence in } \\
\text { patients }\end{array}$ & NA & Unknown \\
\hline
\end{tabular}

NA: not applicable. 
prioritised. That is no longer the case and vaccine can be produced in sufficient amounts for groups at both higher and lower risk. For lack of experience with the 'new' seasonal influenza except in its pandemic form, considerations will have to draw on the pandemic experience and public health judgement.

\section{Persons with chronic underlying conditions} The previous risk group guidance for seasonal influenza highlighted persons with chronic diseases [9] (Table 2). In the 2009 influenza $A\left(\mathrm{H}_{1} \mathrm{~N}_{1}\right)$ pandemic those with chronic diseases were also a risk group, though with some differences as there were some new high risk groups like chronic neurological diseases and morbid obesity [12].

\section{Older people}

Older people were another recognised risk group for the 'old' seasonal influenza [9]. In the 2009 influenza $A\left(H_{1} N_{1}\right)$ pandemic they had a low incidence of influenza probably due to pre-existing immunity. However, the risk of complications and death in older people who were infected was higher than in any other age group [12]. They will also be at risk from $\mathrm{A}\left(\mathrm{H}_{3} \mathrm{~N}_{2}\right)$ and $B$ influenzas. When there is no shortage of vaccine the existing limited evidence and public health considerations would therefore support efforts to vaccinate even healthy older people.

\section{Pregnant women}

The evidence for risk of complications from the 'old' seasonal influenza in otherwise healthy pregnant women was contradictory [14]. With the pandemic influenza, however, they were one of the risk groups, though European data are as yet scarce [12]. Whether they will still be at increased risk with the 'new' seasonal influenza is unclear [2]. In some countries, vaccination coverage with pandemic vaccine in pregnant women was high last autumn, but vaccination started too late to give clear indications of effectiveness. The safety record has been reassuring [13]. For this group the probable risk of complications from influenza infection will have to be weighed against a reluctance to vaccinate pregnant women in some countries and the limited knowledge about vaccine effectiveness. Questions about adjuvanted vaccines may not arise, because most manufacturers have stated they will not be using adjuvants for the seasonal vaccines.

\section{Children}

There has been a general recommendation in the US and also in a few European countries (Finland and some other) for vaccination of all children older than six months against seasonal influenza [15]. The documentation of the burden of disease presented by the 'old' seasonal influenza in Europe was considered too limited to produce general guidance [16]. However, the incidence of paediatric disease and complications during the pandemic waves was considerable [12].

There are practical difficulties in introducing general paediatric influenza immunisation. Immunisation of immunologically naïve young children may require two doses of vaccine. The more acceptable nasal live attenuated vaccines are not available in Europe, and scheduling injectable doses between the vaccines already recommended for infants in the childhood immunisation programmes is a problem. These difficulties must be weighed against the risk of severe influenza outcomes and the possibility of indirectly protecting other risk groups by vaccinating children [17].

\section{Healthy young adults}

One of the unusual features of the 2009 pandemic influenza $\mathrm{A}\left(\mathrm{H}_{1} \mathrm{~N}_{1}\right)$ was the appearance of complications and deaths in young, healthy adults [12]. This is a phenomenon also seen in other pandemics, most clearly in the 'Spanish Flu' 1918-20. It is unknown whether an increase in the rates of complications in healthy young adults will occur during the next influenza season, but the US has included them in their targeted groups for immunisation to the effect that vaccination is recommended for everyone over the age of six months (although actual coverage for this group is well under $50 \%$ ) [18]. This is one of the fields where more knowledge is most needed, and decisions are most difficult.

\section{Healthcare workers}

Information on policies, practices, and coverage for influenza vaccination in Europe is gathered through annual surveys by the Vaccine European New Integrated Collaboration Effort (VENICE) Project [15]. These surveys document that among the many potential target groups healthcare workers are the group most commonly identified for vaccination, and ECDC guidance has highlighted them because of their risk of transferring the infection to persons in the risk groups [12].

\section{Conclusion}

There will inevitably be epidemics of influenza during the winter of $2010-11$, with the new influenza $A\left(\mathrm{H}_{1} \mathrm{~N}_{1}\right)$ probably dominating. However, the scientific information for evidence-based guidance for vaccination is presently insufficient for a more precise guidance. To fulfil its new obligations, ECDC will be undertaking annual reviews of the accumulating information that will first come from the southern hemisphere from July 2010 onwards and then every year in the European influenza seasons.

In the meantime the public health justification for vaccinating people from the age of six months with chronic diseases, older people and healthcare workers seems to be sufficient to identify them as target groups for vaccination. There are also some reasons to believe that pregnant women, young children and young healthy adults will be at risk from a seasonal influenza dominated by the new influenza $A\left(\mathrm{H}_{1} \mathrm{~N}_{1}\right)$ viruses. This must be weighed against the limited knowledge about vaccine effect, the costs and the practical difficulties related to vaccination when the recommendations for the coming season are decided. 


\section{Acknowledgements}

The authors wish to thank Bruno Ciancio for his comments on an earlier draft of this paper.

\section{References}

1. Nicoll A. A new decade, a new seasonal influenza: the Council of the European Union Recommendation on seasonal influenza vaccination. Euro Surveill. 2010;15(1). pii $=19458$ Available from: http://www.eurosurveillance.org/ViewArticle. aspx?Articleld $=19458$

2. European Centre for Disease Prevention and Control. Forward Look Risk Assessment. Likely scenarios for influenza in 2010 and the 2010/2011 influenza season and the consequent work priorities. Stockholm: European Centre for Disease Prevention and Control; March 2010. Available from: http://ecdc.europa. eu/en/healthtopics/H1N1/Documents/1003_RA_forward_look_ influenza.pdf

3. Factsheet - Citizen's version. Seasonal Influenza - Basic facts. Stockholm: European Centre for Disease Prevention and Control; March 2010. Available from: http://ecdc.europa. eu/en/healthtopics/Documents/0712_seasonal_influenza_ factsheet_citizen.pdf

4. Tillett HE, Smith JWG, Clifford RE. Excess morbidity and mortality associated with influenza in England and Wales. Lancet. 1980;1(8172):793-5.

5. Nogueira PJ, Nunes B, Machado A, Rodrigues E, Gómez V, et al. Early estimates of the excess mortality associated with the 2008-9 influenza season in Portugal. Euro Surveill. 2009;14(18). pii=19194. Available from: http://www. eurosurveillance.org/ViewArticle.aspx?Articleld=19194

6. CDC Estimates of $2009 \mathrm{H}_{1} \mathrm{~N}_{1}$ Influenza Cases, Hospitalizations and Deaths in the United States, April 2009 - January 16, 2010. Atlanta: Centres for Disease Control and Prevention; 8 March 2010. Available from: http://www.cdc.gov/h1n1flu/estimates/ April_January_16.htm

7. Recommended viruses for influenza vaccines for use in the 2010-2011 northern hemisphere influenza season. Wkly Epidemiol Rec. 2010;85(10):81-92. Available from: http://www. who.int/wer/2010/wer8510.pdf

8. Jackson C, Vynnycky E, Mangtani P. Estimates of the transmissibility of the 1968 (Hong Kong) Influenza Pandemic: Evidence of Increased Transmissibility Between Successive Waves. Am J Epidemiol. 2010;171(4):465-78.

9. Nicoll A, Ciancio BC, Tsolova S, Blank PR, Yilmaz C. The scientific basis for offering seasonal influenza immunisation to risk groups in Europe. Euro Surveill. 2008;13(43). pii=19018. Available from: http://www.eurosurveillance.org/ViewArticle. aspx?Articleld $=19018$

10. Council of the European Union. Council Recommendation of 22 December 2009 on seasonal influenza vaccination (Text with EEA relevance)(2009/1019/EU). Official Journal of the European Union. 2009. L 348/71. Available from: http://eur-lex.europa. eu/LexUriServ/LexUriServ.do?uri=0J:L:2009:348:0071:0072:E $\mathrm{N}: \mathrm{PDF}$

11. Strategic Advisory Group of Experts on Immunization - report of the extraordinary meeting on the influenza $A\left(\mathrm{H}_{1} \mathrm{~N}_{1}\right) 2009$ pandemic, 7 July 2009. Wkly Epidemiol Rec. 2010;84(30):301-4. Available from: http://www.who.int/entity/wer/2009/wer8430. pdf

12. European Centre for Disease Prevention and Control. ECDC Risk Assessment. 2009 influenza $A\left(\mathrm{H}_{1} \mathrm{~N}_{1}\right)$ pandemic. Version 7. Stockholm: European Centre for Disease Prevention and Control; 17 December 2009. Available from: http://ecdc. europa.eu/en/healthtopics/Documents/0908_Influenza_ AH1N1_Risk_Assessment.pdf

13. Updates on pandemic safety monitoring. European Medicines Agency pandemic influenza $\left(\mathrm{H}_{1} \mathrm{~N}_{1}\right)$ website. London: European Medicines Agency; Available from: http://www.ema.europa.eu/ influenza/updates.html

14. Mak TK, Mangtani P, Leese J, Watson JM, Pfeifer D. Influenza vaccination in pregnancy: current evidence and selected national policies. Lancet Infect Dis. 2008;8(1):44-52.

15. National Seasonal Influenza Vaccination Survey in Europe, 2007. Final report. Collaboration between VENICE project and ECDC. VENICE; December 2007-April 2008. Available from: http://venice.cineca.org/Influenza_Study_Report_v1.o.pdf

16. Infant and children seasonal immunisation against influenza on a routine basis during inter-pandemic period. Technical report of the scientific panel on vaccines and immunisation. Stockholm: European Centre for Disease Prevention and Control; January 2007. Available from: http://ecdc.europa.eu/ en/publications/Publications/0701_TER_Scientific Panel on Vaccines_and_Immunisation.pdf
17. Loeb M, Russell ML, Moss L, Fonseca K, Fox J, Earn DJ, et al. Effect of Influenza Vaccination of Children on Infection Rates in Hutterite Communities: A Randomized Trial. JAMA. 2010;303(10):943-50.

18. Advisory Committee on Immunization Practices. ACIP Provisional Recommendations for the Use of Influenza Vaccines. Atlanta: Centers for Disease Control and Prevention; 2 March 2010. Available from: http://www.cdc.gov/vaccines/ recs/provisional/downloads/flu-vac-mar-2010-508.pdf 